\title{
INFLUENCE OF THE DEGREE OF EJACULATE DILUTION ON THE RESULTS OF THE ASSESSMENT OF MOTILITY OF SPERM OF BREEDING BULLS OBTAINED BY TWO METHODS
}

\author{
WPŁYW STOPNIA ROZRZEDZENIA EJAKULATU NA WYNIKI \\ OCENY RUCHLIWOŚCI PLEMNIKÓW BUHAJÓW PRZEPROWADZONEJ \\ DWIEMA METODAMI
}

Institute of Animal Breeding, Wrocław University of Environmental and Life Sciences, Poland

\begin{abstract}
Streszczenie. Przeprowadzone doświadczenie miało na celu zbadania efektywności dwóch metod oceny parametrów ruchu plemników w nasieniu rozmrożonym, w zależności od stopnia jego rozrzedzenia. Nasienie pobrano od 12 buhajów rasy simentalskiej przy użyciu sztucznej pochwy. Próbki nasienia oceniono wstępnie pod względem objętości, barwy, pH, żywotności, koncentracji i ruchliwości, a następnie połączono w jedną próbę zbiorczą w celu eliminacji różnic indywidualnych, schłodzono do temperatury $4^{\circ} \mathrm{C}$, zapakowano w słomki $(0,25 \mathrm{ml})$ i zamrożono w ciekłym azocie po czym, przechowywano w kontenerze w temperaturze $-196^{\circ} \mathrm{C}$. Następnie rozmrożono, podzielono na próby A, B i C oraz rozrzedzono kolejno w stosunku $1: 10$ (próba A), $1: 20$ (próba B) i $1: 30$ (próba C); poddano ocenie wybrane parametry ruchu przy użyciu konwencjonalnej metody mikroskopowej oraz metody wspomaganej komputerowo (CASA). Uzyskane wyniki opracowano statystycznie. Całkowity ruch plemników analizowany dwiema metodami we wszystkich badanych próbach różnił się istotnie ( $p<0,05)$. Ruch postępowy plemników badany w systemie CASA różnił się istotnie od badanego w przypadku użycia konwencjonalnej metody, przy rozrzedzeniu $1: 20$ oraz $1: 30(p<0,05)$. Uzyskane wyniki ruchu postępowego przy rozrzedzeniu 1:20 z użyciem obu metod nie różniły się istotnie. Badania wykazały, że analiza ruchliwości przeprowadzona za pomocą systemu CASA cechowała się większą dokładnością i powtarzalnością wyników niż konwencjonalna metoda mikroskopowa. Ponadto wyniki poniższych badań wskazują na zależność pomiędzy stopniem rozrzedzenia nasienia a powtarzalnością wyników.
\end{abstract}

Key words: cattle, computer analysis of semen, frozen semen, motility.

Słowa kluczowe: bydło, komputerowa analiza nasienia, mrożone nasienie, ruchliwość.

\section{INTRODUCTION}

Artificial insemination, embryo transfer, in vitro fertilization, cloning, transgenicity and genomics are elements of the toolkit necessary for the development of the emerging new biotechnologies and the response to the growing demand in the market. Combining these technologies with modern laboratory equipment, information systems and data analysis will provide an even more powerful tool for significantly improving productivity. Cryopreservation

Corresponding author - Adres do korespondencji: Marian Kuczaj, Institute of Animal Breeding, Wrocław University of Environmental and Life Sciences, Chelmońskiego 38C, 51-630 Wrocław, Poland, e-mail: marian.kuczaj@upwr.edu.pl 
of biological material of cattle gave breeders the opportunity to choose the best breeders, after prior assessment of the genetic value and use it on a large scale, because with current methods of preservation of semen one can produce several hundred insemination doses from one collected ejaculate of bull. During a year, several dozen thousands of portions of semen may be obtained by collecting semen from a bull. Unfortunately, apart from many advantages offered by the possibility of freezing and storing semen, as reported by many authors, the process of its cryopreservation carries with it the negative effects of this technological process (Bailey et al. 2000; Watson 2000; Januskauskas et al. 2003; Meyers 2005; Pena et al. 2009). One of them is the weakening of sperm motility, which is a decisive factor in the fertilization process (Bongso et al. 1989; Kasai et al. 2002; Alragubi 2014). Unfortunately, although scientists have tried to develop techniques for accurately predicting the fertilization of sperm samples from a single male for centuries, this goal has not been achieved (Amann and Hammerstedt 1993). This is partly due to the fact that studies on sperm quality and fertility have produced inconsistent results (Dalton 2011). Incorrect functioning of one of the many important and independent qualities of sperm may result in the fact that the given spermatozoon will not be able to fertilize (Amann and Katz 2004). Thus, the produced straw with the seed will be worthless.

With the increase of competitiveness on the market for the production of sperm, the quality of the final product, which is sperm in straw, become important. In order to obtain a good product that stands out from other available on the market, semen producers decide to introduce modern technologies to improve the work of semen assessment laboratories and improve methods of evaluation of ejaculates that end up in insemination straws. So far, standard macro and microscopic techniques based on subjective visual assessment of sperm parameters have been widely used for the purpose of analysing the quality parameters of semen. With the development of technology, flow cytometers (Ormerod 1993) and computer-assisted sperm analysis systems (CASA) were introduced to the market (Dott and Foster 1979).

Among many factors determining the effectiveness of fertilization is the sperm motility (Donnelly et al. 1998). The function of motility plays an important role when spermatozoa reach the uterine body, which contains mucus (Jansen 1978; Jansen and Bajpai 1982; Cox et al. 2006) and may constitute a barrier for sperm with poor motor skills (Mortimer 1997; Robayo et al. 2008). Therefore, it is very important to accurately estimate this parameter so that the semen introduced to the market is characterized by the best motor activity, assessed by the most reliable technique.

For the determination of sperm parameters such as the degree of agglutination, mass wave motion and individual spermatozoa movement in humans and most animal species, conventional microscopic analysis has been used for years (Mortimer et al. 1986; Aitken et al. 1982; Klimowicz et al. 2005a).

The main problem in using the standard microscopic technique is subjectivity and variability, which translates into the final result and interpretation. The evaluation of sperm motility is influenced by many factors, the most important of which is the experience and skills of the evaluator (Yeung et al. 1997). The evaluator, guided by experience subjectively evaluates the image he sees, hence the differences in the results between different 
evaluators. Other authors also report the subjectivity of the sperm motility assessment by the human eye (Amann 1989; Rozeboom 2000). An important problem is also a small percentage of sperm tested. There is therefore a need for accurate, objective and standardized methods for semen assessment.

The Computer Assisted Sperm Analysis (CASA) has been successfully used in both human and veterinary medicine for nearly 25 years (Agarwal et al. 1992; Davis and Katz 1992; Crockett et al. 2001; Klimowicz et al. 2005b). CASA allows for objective, simultaneous, reliable, fast and very accurate analysis of several parameters of sperm movement, such as: total mobility, percentage of progressive spermatozoa, linearity of movement or speed parameters (Verstegen et al. 2002). The CASA system provides a high level of precision and reliability in the evaluation and classification of sperm, however, it is not widely used in veterinary practice. Mainly due to the high cost of the software itself and the cost of use. The CASA system requires standardization and validation before use, and image settings have been unified for humans and other species (Iguer-ouada and Verstegen 2001; Tejerina et al. 2008). The correct result is influenced by the type and depth of the chamber used, the number of analysed fields, the temperature of the analysis and the protocol of sample preparation of the semen (Rijsselaere et al. 2003). Many authors, however, report that the CASA system in comparison to microscopic analysis is the most standardized and highly objective (Abaigar et al. 1999; Hoflack et al. 2007). Thanks to the microscopic images recorded by video camera, the CASA system analyzes it, thanks to the transformation of individual pixels.

The registered sperm positions allow to plot their path, its measurement and determination of movements of subsequent spermatozoa. Thanks to this, it enables the visualization of the movement path of individual gametes, which in turn allows a detailed description of parameters related to the speed and type of sperm movement.

The aim of this study was to compare the effectiveness of two methods of sperm motility assessment in frozen semen of breeding bulls using different degrees of dilution.

\section{MATERIAL AND METHODS}

Animals and semen collection. The study involved a group of 12 Simmental breeding bulls at the age of 3, from Germany, kept and fed equally. The experiment was carried out at the Małopolska Centre of Biotechnology in Krasne. The subject of the analysis was semen taken with an artificial vagina, twice a week at 7 am, for 11 weeks (the total number of ejaculates tested was 792).

Semen processing. The semen, after collection, was placed in a water bath at $38^{\circ} \mathrm{C}$ until the initial assessment, in which the volume of each ejaculate was considered, measured by means of a graduated test-tube, the colour of ejaculate and $\mathrm{pH}$ (litmus paper). After initial assessment, the ejaculates were combined to eliminate individual differences and viability via flow cytometer (CytoFlex Beckman Coulter, B3-R1-V0, China) and concentration by photometric method (Dr. Lange, LP 300 SDM; Minitube, Tiefenbach b. Landshut, Germany) in accordance with the standard procedure for the production of semen in the Małopolska Centre of Biotechnology. Semen samples that showed more than $60 \%$ sperm viability were 
further processed. For this purpose, the semen was diluted to a final concentration of $120 \times 106$ spermatozoa/ml by commercial diluent BIOXcell ${ }^{\circledR}$ (IMV, France). It was then packaged automatically (Bloc Machine FIN, IS 4, France) in $0.25 \mathrm{ml}$ straw (PVC, Biovet, France) and subjected to equilibration $\left(1.5 \mathrm{~h}, 4^{\circ} \mathrm{C}\right)$. After equilibration, the semen was frozen using an automatic freezer (IMV Technologies, France) according to the method described by Pürhan et al. (2010). Frozen straws were placed in a container with liquid nitrogen and stored until analysis.

Frozen straws with semen were placed in a water bath, thawed at $38^{\circ} \mathrm{C}$ for 20 seconds, diluted 1:10, 1:20, 1:30 and immediately evaluated using two methods.

Analysis of sperm motility. The semen described below was evaluated by one person. Two straws from the same day of collection/production were used for each replicate.

Conventional assessment of motility. The mass wave motion (100x) was determined in $20 \mu \mathrm{l}$ of unseparated semen using the scale: + no movement, ++ free spermatozoa, moving without wave formation, +++ strong movement with visible wave, ++++ very strong movement with a rapidly moving wave, using a Bloom table in a layer with a thickness of $350 \mu \mathrm{m}$.

$21 \mu \mathrm{l}$ of thawed semen were used to assess total and progressive movement, which were diluted successively in proportions: sample $A ; 1: 10$; sample $B ; 1: 20$; sample $C ; 1: 30$ and placed on a pre-heated $\left(38^{\circ} \mathrm{C}\right)$ Bloom glass and covered with a cover glass. The total sperm movement, and progressive movement (400x) were evaluated under a microscope (Nikon E 200, China) (Biswas et al. 2002). The total sperm movement and the progressive movement were rated subjectively on a scale from $0 \%$ (no movement) to $100 \%$ (very good movement), in a $5 \mu \mathrm{m}$ thick layer. Each sample was analyzed in four different fields of view.

Computer evaluation of motility. For computer-assisted evaluation, $1 \mu \mathrm{l}$ of thawed semen was collected, which was diluted with $0.9 \% \mathrm{NaCl}$ solution in the ratio of $\mathrm{A}: 1: 10$; sample $B: 1: 20$ and sample $C: 1: 30$, then $2 \mu \mathrm{L}$ of the seed thus prepared was placed in the Leja chamber (Leja Products BV, Netherlands) and evaluated using Sperm Class Analyzer (SCA, version 5.1, Microptic, Barcelona, Spain) in terms of total sperm movement, progressive movement and sperm speed parameters (VAP (Average Path Velocity) average path of consecutive registered positions, VCL (Curvilinear Velocity) - total distance taken by the sperm per unit of time, VSL (Straight Line Velocity) - path travelled by the sperm in straight line per unit time, ALH (Amplitude of Lateral Head Displacement) amplitude of lateral head deflections, LIN (Linearity) - linearity of sperm movement expressed in VSL/VCL ratio in \%, STR (Straightness) - sperm movement straightness expressed by VSL ratio/VAP in \%, WOB (Wobble) - oscillation ratio expressed in VAP/VCL ratio in \%). Four analyzes were conducted for one sample.

Statistical analysis. Numerical data were presented as mean values. The obtained results were analysed statistically. The analysis of variance (ANOVA) was used to evaluate the differences between the two methods of sperm movement analysis. In order to compare both methods, the Duncan's test (Duncan's multiple range test) was used. Statistica ${ }^{\circledR} 12.0$ (StatSoft ${ }^{\circledR} \mathrm{PL}$ ) was used for statistical analysis. 


\section{RESULTS}

The study material accounted for a total of 792 ejaculates, $67 \%$ were qualified for further research after the preliminary analysis. The detailed analysis covered 22 aggregate tests. The results of the preliminary fresh semen evaluation are presented in Table 1 . The results of the assessment of the viability and concentration of pooled samples before freezing are included in Table 2. Table 3 shows the individual parameters of thawed sperm movement with the help of computer assisted analysis for individual dilution stages. The results of the comparison of the assessment of selected parameters of sperm movement after thawing by conventional and computer-assisted evaluation depending on the degree of dilution are shown in the Table 4.

Table 1. Results of preliminary assessment of the semen of breeding bulls Tabela 1. Wyniki oceny wstępnej świeżego nasienia buhajów

\begin{tabular}{ccc}
\hline $\begin{array}{c}\text { Volume of the ejaculate } \\
\text { Objętość ejakulatu [ml] }\end{array}$ & $\begin{array}{c}\text { Color of the ejaculate } \\
\text { Barwa ejakulatu }\end{array}$ & $\begin{array}{c}\mathrm{pH} \text { of the ejaculate } \\
\mathrm{pH} \text { ejakulatu }\end{array}$ \\
\hline $4.7 \pm 5.29$ & $\begin{array}{c}\text { milky white } \\
\text { mlecznobiała }\end{array}$ & $6.7 \pm 0.23$ \\
\hline
\end{tabular}

Mean values $\pm S D(n=22)-$ Wartości średnie $\pm S D(n=22)$.

The average volume of ejaculate was $4.7 \mathrm{ml}$, the minimum volume of the tested sample was $2.2 \mathrm{ml}$, maximum $5.4 \mathrm{ml}$. The $\mathrm{pH}$ of the ejaculate ranged from 6.4 to 6.8 resulting in an average value of 6.7. Observed colours of ejaculates did not differ significantly from each other. They hesitated from grey, milky to creamy. The predominant ones were milky white.

Table 2. Results of the assessment of the viability and concentration of breeding bulls spermatozoa in a pooled sample before cryopreservation

Tabela 2. Wyniki oceny żywotności i koncentracji nasienia buhajów w próbie zbiorczej przed kriokonserwacją

\begin{tabular}{cc}
\hline & Sperm concentration \\
Spermatozoa viability & [spermatozoa per $\mathrm{mm}^{3}$ ] \\
Żywotność plemników [\%] & Koncentracja plemników \\
& {$\left[\right.$ [ilość plemników na $1 \mathrm{~mm}^{3}$ ] } \\
\hline
\end{tabular}

$73.91 \pm 5.77$

$1224 \times 10^{6} \pm 9.94$

Mean values $\pm S D(n=22)-$ Wartości średnie $\pm S D(n=22)$.

The average percentage of alive spermatozoa in the semen collection sample before freezing was $73.91 \%$. The lowest percentage of alive spermatozoa recorded was $66.34 \%$, while the maximum percentage was $79.26 \%$. The average concentration of sperm in a cubic millimeter was 1224 million. The lowest concentration was 996 million, the highest 2044 million. 
Table 3. Values of spermatozoa movement parameters obtained during computer-assisted sperm analysis (CASA) in thawed semen of breeding bulls, depending on the degree of its dilution

Tabela 3. Wartości parametrów ruchu plemników uzyskane podczas komputerowej analizy nasienia (CASA) w nasieniu rozmrożonym buhajów, w zależności od stopnia jego rozrzedzenia

\begin{tabular}{|c|c|c|c|c|c|c|c|}
\hline \multirow{2}{*}{$\begin{array}{l}\text { Dilution degree } \\
\text { Stopień } \\
\text { rozrzedzenia }\end{array}$} & VSL & VCL & VAP & LIN & STR & WOB & $\mathrm{ALH}$ \\
\hline & \multicolumn{3}{|c|}{$\mu \mathrm{m} \cdot \mathrm{s}^{-1}$} & \multicolumn{3}{|c|}{$\%$} & $\mu \mathrm{m}$ \\
\hline $\begin{array}{l}\text { Sample A } \\
\text { Próba A } \\
1: 10\end{array}$ & $\begin{array}{c}42.70 \pm \\
0.33\end{array}$ & $\begin{array}{c}66.94 \pm \\
0.42\end{array}$ & $\begin{array}{c}51.35 \pm \\
0.21\end{array}$ & $\begin{array}{c}63.79 \pm \\
0.36\end{array}$ & $\begin{array}{c}83.16 \pm \\
0.25\end{array}$ & $\begin{array}{c}76.71 \pm \\
0.39\end{array}$ & $\begin{array}{c}2.97 \pm \\
0.09\end{array}$ \\
\hline $\begin{array}{l}\text { Sample B } \\
\text { Próba B } \\
1: 20\end{array}$ & $\begin{array}{c}46.61 \pm \\
0.12\end{array}$ & $\begin{array}{c}68.49 \pm \\
0.26\end{array}$ & $\begin{array}{c}55.12 \pm \\
0.29\end{array}$ & $\begin{array}{c}66.01 \pm \\
0.09\end{array}$ & $\begin{array}{c}86.34 \pm \\
0.08\end{array}$ & $\begin{array}{c}79.13 \pm \\
0.11\end{array}$ & $\begin{array}{c}2.99 \pm \\
0.06\end{array}$ \\
\hline $\begin{array}{l}\text { Sample C } \\
\text { Próba C } \\
1: 30\end{array}$ & $\begin{array}{c}40.96 \pm \\
0.19\end{array}$ & $\begin{array}{c}66.01 \pm \\
0.21\end{array}$ & $\begin{array}{c}52.32 \pm \\
0.28\end{array}$ & $\begin{array}{c}64.55 \pm \\
0.08\end{array}$ & $\begin{array}{c}79.99 \pm \\
0.04\end{array}$ & $\begin{array}{c}74.22 \pm \\
0.06\end{array}$ & $\begin{array}{l}2.86 \pm \\
0.005\end{array}$ \\
\hline
\end{tabular}

Mean values $\pm S D(n=22)-$ Wartości średnie $\pm S D(n=22)$.

The minimum value for the VSL parameter was recorded in the sample $C(1: 30)$, i.e. $40.96\left(\mu \mathrm{m} \cdot \mathrm{s}^{-1}\right)$, while the maximum was observed in the sample $B(1: 20)$ and it was $46.61\left(\mu \mathrm{m} \cdot \mathrm{s}^{-1}\right)$. Similar results were obtained by studying the parameters VCL, STR, WOB and $\mathrm{ALH}$. In the case of the VAP parameter, the minimum value was recorded in sample $A$ $(1: 10)$, i.e. $51.35\left(\mu \mathrm{m} \cdot \mathrm{s}^{-1}\right)$, while the maximum in the sample $B(1: 20)$ i.e. $55.12\left(\mu \mathrm{m} \cdot \mathrm{s}^{-1}\right)$.

Table 4. The sperm motility parameters in the thawed semen of breeding bulls obtained according to the studied methods, depending on the degree of its dilution

Tabela 4. Uzyskane badanymi metodami parametry ruchliwości plemników w nasieniu rozmrożonym buhajów, w zależności od stopnia jego rozrzedzenia

\begin{tabular}{|c|c|c|c|c|}
\hline \multirow{3}{*}{$\begin{array}{l}\text { Degree } \\
\text { of dilution } \\
\text { Stopień } \\
\text { rozrzedzenia }\end{array}$} & \multicolumn{2}{|c|}{$\begin{array}{l}\text { Total spermatozoa movement } \\
\text { Całkowity ruch plemników [\%] }\end{array}$} & \multicolumn{2}{|c|}{$\begin{array}{l}\text { Progressive movement } \\
\text { Ruch postępowy [\%] }\end{array}$} \\
\hline & \multicolumn{4}{|c|}{$\begin{array}{l}\text { method } \\
\text { metoda }\end{array}$} \\
\hline & $\begin{array}{c}\text { conventional } \\
\text { konwencjonalna }\end{array}$ & CASA & $\begin{array}{l}\text { conventional } \\
\text { konwencjonalna }\end{array}$ & CASA \\
\hline $\begin{array}{l}\text { Sample A } \\
\text { Próba A } \\
1: 10\end{array}$ & $45.00^{\mathrm{aA}} \pm 0.37$ & $53.45^{\mathrm{bA}} \pm 2.26$ & $35.00^{\mathrm{aA}} \pm 0.22$ & $29.35^{\mathrm{bA}} \pm 5.72$ \\
\hline $\begin{array}{l}\text { Sample B } \\
\text { Próba B } \\
1: 20\end{array}$ & $52.00^{\mathrm{aB}} \pm 5.99$ & $57.13^{\mathrm{bB}} \pm 0.21$ & $35.50^{\mathrm{aA}} \pm 0.35$ & $22.77^{a B} \pm 0.17$ \\
\hline $\begin{array}{l}\text { Sample C } \\
\text { Próba C } \\
1: 30\end{array}$ & $38.00^{\mathrm{aBC}} \pm 6.04$ & $56.56^{\mathrm{bB}} \pm 0.23$ & $30.00^{\mathrm{aB}} \pm 1.12$ & $21.54^{\mathrm{bB}} \pm 0.09$ \\
\hline
\end{tabular}

Mean values $\pm S D(n=22)$. Different letters in the same row within the tested parameter indicate significant differences: $a, b ; p<0.05$. Different letters in the same column indicate significant differences: $A, B ; p<0.05$. Wartości średnie \pm S.D $(n=22)$.

Różne litery w tym samym wierszu w obrębie badanego parametru wskazują na istotne różnice; $a, b ; p<0,05$. Różne litery w tej samej kolumnie wskazują na istotne różnice; $A, B ; p<0,05$. 
The mean value of total sperm movement when tested using the conventional method. In diluted semen in $1: 10$ it was $45.00 \%$ and was significantly lower $(p<0.05)$ than the result obtained with the CASA system, which was $53.45 \%$, respectively. The opposite situation occurred in the case of determining the average progressive movement in the same sample. The value obtained by the conventional method was significantly higher $(p<0.05)$ than the result obtained with the help of computer-assisted analysis. In the sample B (dilution in the ratio $1: 20)$ a significant difference $(p<0.05)$ was observed in the total sperm movement assessed by the two above methods, however, the progressive movement assessed in this test, depending on the method used, did not differ significantly $(p>0.05)$. The progressive movement and total movement of sperm tested using the two methods above in the $C$ test $(1: 30)$ showed significant differences in the results obtained with two methods $(p<0.05)$. The above data show that the degree of dilution had a significant impact on the obtained results. In the conventional method, the average standard deviation from the obtained results increased with the degree of dilution. In the computer-assisted method, the reproducibility of results increased with the increasing degree of dilution. The degree of dilution had a significant effect $(p<0.05)$ on the obtained result of the total sperm movement when tested by the conventional method, while the same parameter analysed using the CASA system showed the significance of differences between $A$ and $B$ and $A$ and $C$. No significant differences were found in the assessment of the above parameter between samples $B$ and $C$ tested using a computer assisted method. The significance of the differences $(p<0.05)$ was observed in the evaluation of the progressive movement using both methods in samples $A$ and $C$, with the conventional method $(p<0.05)$ significant differences in the $B$ and $C$ sample, whereas with the CASA method in A and B sample.

\section{DISCUSSION}

The usefulness of the semen for artificial insemination is determined by the result of testing its parameters. A normalized, objective and accurate way to analyze the characteristics of semen allows to obtain a very good quality end product, which is a straw with sperm. In this study, attention was paid to sperm parameters in the initial assessment, such as volume, $\mathrm{pH}$ and color of ejaculates, and results similar to other authors were obtained (Javed et al. 2000; Sarsaifi et al. 2013; Bhakat et al. 2014). Also the results of the viability and concentration assessment of semen were correct and similar to those obtained by Garner et al. (1997). Thanks to the technological possibilities of computerized semen analysis, detailed motility parameters were analyzed that corresponded to the results obtained by Contri et al. (2010) and Sundararaman et al. (2012).

Mobility is considered the most important feature associated with the sperm's ability to fertilize (Kathiravan et al. 2011). Therefore, it is important that the obtained result is the most reliable. The above studies indicate that the obtained results by conventional microscopic method differ significantly from the results obtained using the CASA system, which is confirmed by other authors (Verstegen et al. 2002; Rijsselaere et al. 2003). Total sperm motility examined by microscopy at $1: 10,1: 20$ and $1: 30$ dilution was lower than obtained by computer assisted analysis by $8.45 \%, 5.13 \%$ and $18.56 \%$. 
The main problem is the subjective estimation of the assessed motility due to the high concentration of spermatozoa and their speed of movement in the field of view. The CASA system eliminates this error and therefore reports lower values of progressive mobility than the „manual" estimation (Davis 1992). This is confirmed by the result of this study, showing a $5.65 \%(1: 10)$ lower percentage of spermatozoa with progressive movement estimated using the CASA system than with the conventional method $-12.73 \%$ for $1: 20$ dilution and $8.46 \%$ for $1: 30$ dilution. However, the effect of the degree of dilution has a significant impact on the results obtained by the conventional method, as well as on those obtained with the CASA system. The results of the above studies show the relationship between the degree of sperm dilution and the reproducibility of the results obtained with the help of both methods. In the case of conventional evaluation, the higher the degree of dilution, the higher the standard deviation. In turn, the results obtained by means of computer assisted analysis were more repeatable with a higher degree of dilution. The above data indicate that the CASA system requires adequate dilution of the test sample. Mostafapor and Ardebili (2014) also report that the degree of sperm dilution for analysis with the CASA system has an effect on errors in results caused by sperm collisions. Contri et al. 2010 report the necessity of appropriate dilution of test semen in order to increase the ability of the device to perform the analysis. Nevertheless, many authors confirm the high accuracy and repeatability of results obtained by means of computer assisted analysis (Davis et al. 1992; Farrell et al. 1995).

\section{CONCLUSIONS}

The results of the effectiveness analysis of two methods of sperm motility assessments in breeding bulls ejaculates indicate that computer-assisted sperm analysis is more useful, more versatile, more accurate and more objective than conventional microscopic method. The measurement stability and reproducible results obtained with the CASA system make it unrivalled in comparison to the conventional microscopic method and should be used for routine analysis of semen quality in breeding bull semen production stations.

The following conclusions can be drawn from the conducted research:

1. The computer-assisted microscopic method (CASA) is a significantly more perfect tool for studying the motility of breeding bulls sperms compared to the conventional microscopic method.

2. There is a significant relationship between the degree of sperm dilution and the reproducibility of results. The progressive movement of spermatozoa studied with two methods differed significantly only at $1: 20$ and $1: 30$ dilution.

3. The CASA method should be preferred to routine testing of sperm motility in breeding bulls ejaculates.

\section{REFERENCES}

Abaigar T., Holt W.V., Harrison R.A., Barrio G. del. 1999. Sperm subpopulations in boar (Sus scrofa) and gazelle (Gazella dama mhorr) semen as revealed by pattern analysis of computer assisted motility assessments. Biol. Reprod. 60, 32-41. 
Agarwal A., Ozturk E., Loughlin K.R. 1992. Comparison of semen analysis between the two Hamilton-Thorn semen analysers. Andrologia 24, 327-329.

Aitken R.J., Best F.S.M., Richardson D.W., Djahanbakhch O., Mortimer D., Templeton A.A. 1982. An analysis of sperm function in cases of unexplained infertility: conventional criteria, movement characteristics, and fertilizing capacity. Fertil. Steril. 38, 212-221.

Alragubi S. 2014. Effect of sperm quality of beef cattle on fertility percentage. Int. J. Sci. Res. 3, 790-793.

Amann R.P. 1989. Can the fertility potential of a semen sample be predicted accurately? J. Androl. 10, 89-98.

Amann R.P., Katz D.F. 2004. Reflections on CASA after 25 years. J. Androl. 25(3), 317-325.

Amann R.P., Hammerstedt R.H. 1993. In vitro evaluation of sperm quality: An opinion. J. Androl. 14(6), 397-406.

Bailey J.L., Bilodeau J.F., Cormier N. 2000. Semen cryopreservation in domestic animals: a damaging and capacitating phenomenon. J. Androl. 21, 1-7.

Bhakat M., Mohanty T.K., Gupta A.K., Abdullah M. 2014. Effect of season on semen quality of crossbred (Karan Fries) bulls. Advances Anim. Vet. Sci. 2(11), 632-637.

Biswas D., Bari F.Y., Shamsuddin M., Rahmand M.M., Rahman M.M. 2002. Determination of glycerol percentage for preserving the black Bengal buck (Capra hircus) spermatozoa for long time. Pak. J. Biol. Sci. 5(6), 715-718

Bongso T.A. Ng. S.C., Mok H., Lim M.N., Teo H.L., Wong P.C., Ratnam S.S. 1989. Effect of sperm motility on human in vitro fertilization. Arch. Androl. 22(3), 185-190.

Contri A., Valorz C., Faustini M., Wegher L., Carluccio A. 2010. Effect of semen preparation on casa motility results in cryopreserved bull spermatozoa. Theriogenology 74(3), 424-435.

Cox J.F., Alfaro V., Montenegro H. 2006. Computer-assisted analysis of sperm motion in goats and its relationship with sperm migration in cervical mucus. Theriogenology 66(4), 860-867.

Crockett E.C., Graham J.K., Bruemmer J.E. 2001. Effect of cooling of equine spermatozoa before freezing on post-thaw motility: preliminary results. Theriogenology $55,793-803$.

Dalton J. 2011. Semen quality factors associated with fertility. Applied Reproductive Strategies in Beef Cattle- Proceedings 1, 265-281.

Davis R.O., Katz D.F. 1992. Standardization and comparability of CASA instruments. J. Androl. 13, 81-86.

Davis R.O., Rothmann S.A., Overstreet J.W. 1992. Accuracy and precision of computer-aided sperm analysis in multicenter studies. Fertil Steril. 57, 648-653.

Donelly E.T., Scheena E.M., MC Nally J.A., Thompson W. 1998. In vitro fertilization and pregnancy rates: the influence of sperm motility and morphology on IVF outcome. Fert. Steril. 70(2), 305-314.

Dott H.M., Foster G.C. 1979. The estimation of sperm motility in semen, on a membrane slide, by measuring the area change frequency with an image analyzing computer. J. Reprod. Fertil 55, 161-166.

Farrell P.B., Trouern-Trend V., Foote R.H., Douglas-Hamilton D. 1995. Repeatability of measurements on human, rabbit, and bull sperm by computer-assisted sperm analysis when comparing individual fields and means of 12 fields. Fertil. Steril. 64, 208-210.

Garner D.L., Thomas C.A., Allen C.H. 1997. Effect of semen dilution on bovine sperm viability as determined by dual-DNA staining and flow cytometry. J. Androl. 18(3), 324-331.

Hoflack G., Opsomer G., Rijsselaere T., Van Soom A., Maes D., Kruif A. de, Duchateau L. 2007. Comparison of computer-assisted sperm motility analysis parameters in semen from Belgian Blue and Holstein-Friesian bulls. Reprod. Domest. Anim. 42, 153-161.

Iguer-Ouada M., Verstegen J.P. 2001. Evaluation of the „Hamilton Thorn computer-based automated system" for dog semen analysis. Theriogenology 55, 733-749.

Jansen R.P.S. 1978. Fallopian tube isthmic mucus and ovum transport. Science 201, 349-351.

Jansen R.P.S., Bajpai V.K. 1982. Oviduct mucus glycoproteins in the estrus rabbit: ultrastructure and histochemistry. Biol. Reprod. 26, 155- 68. 
Januskauskas A., Johannisson A., Rodriguez-Martinez H. 2003. Subtle membrane changes in cryopreserved bull semen in relation with sperm viability, chromatin structure, and field fertility. Theriogenology 60, 743-758.

Javed M.T., Khan A., Kausar R. 2000. Effect of age and season on some semen parameters in Sahiwal bulls. Vet. Archiv. 70, 83-94.

Kasai T., Ogawa K., Mizuno K., Nagai S., Uchida Y., Ohta S., Fujie M., Suzuki K., Hirata S., Hoshi K. 2002. Relationship between sperm mitochondrial membrane potential, sperm motility, and fertility potential. Asian J. Androl. 4, 97-103.

Kathiravan P., Kalatharan J., Karthikeya G., Rengarajan, Kadirvel G. 2011. Objective sperm motion analysis to assess dairy bull fertility using computer-aided system: a review. Reprod. Dom. Anim. 46, 165-172.

Klimowicz M., Łukaszewicz E., Dubiel A. 2005a. Effect of collection frequency on quantitative and qualitative characteristics of pigeon. Br. Poult Sci. 46, 361-365.

Klimowicz M., Niżański W., Savic M.A., Zbyryt I., Dubiel A. 2005b. Ocena jakości nasienia psa przy zastosowaniu konwencjonalnej metody mikroskopowej, cytometru przepływowego oraz komputerowego analizatora jakości nasienia HTM IVOS [Assessment of dog semen quality using a conventional microscopic method, flow cytometer and HTM IVOS semen quality computer analyzer]. Med. Weter. 61, 1250-1255. [in Polish]

Meyers S.A. 2005. Spermatozoal response to osmotic stress. Anim. Reprod. Sci. 89, 57-64.

Mortimer S.T. 1997. A critical review of the physiological importance and analysis of sperm movement in mammals. Hum. Reprod. 3, 403-439.

Mortimer D., Shu M.A., Tan R. 1986. Standardization and quality control of sperm concentration and sperm motility counts in semen analysis. Hum. Reprod. 1, 299-303.

Mostafapor S., Ardebili F.F. 2014. Effects of diluting medium and holding time on sperm motility analysis by CASA in ram. Vet. Res. Forum 5(2), 101-105.

Ormerod M. 1993. Flow cytometry. First principles. J. Clin. Pathol. 46(10), 975.

Pena F.J., Rodriguez-Martinez H., Tapia J.A., Ortega-Ferrusola C., Gonzalez-Fernandez L., Macias-Garcia B. 2009. Mitochondria in mammalian sperm physiology and pathology: a review. Reprod. Dom Anim. 44, 345-349.

Pürhan B.T., Bucak M.N., Büyükleblebici S., Sarıözkan S., Yeni D. 2010. The effect of cysteine and glutathione on sperm and oxidative stress parameters of post-thawed bull semen. Cryobiology 61 , 303-307.

Rijsselaere T., Soom A. van, Maes D., Kruif A. de. 2003. Effect of technical settings on canine semen motility parameters measured by the Hamilton-Thorne analyzer. Theriogenology 60, 1553-1568.

Robayo I., Montenegro V., Valdes C. 2008. CASA assessment of kinematic parameters of ram spermatozoa and their relationship to migration efficiency in ruminant cervical mucus. Reprod. Domest. Anim. 43(4), 393-399.

Rozeboom K.J. 2000. Evaluating boar semen quality. Anim. Sci. Facts. Extension Swine Husbandry ANS 00-812S, https://projects.ncsu.edu/project/swine_extension/publications/factsheets/812s.pdf, access: April 2017.

Sarsaifi K., Rosnina Y., Ariff M.O., Wahid H., Hani H., Yimer N., Vejayan J., Win Naing S., Abas M.O. 2013. Reprod. Domest. Anim. Dec. 48(6), 1006-1012.

Sundararaman M.N., Kalatharan J., Thilak Pon Jawahar K. 2012. Computer assisted semen analysis for quantification of motion characteristics of bull sperm during cryopreservation cycle. Vet. World 5(12), 723-726.

Tejerina F., Buranaamnuay K., Saravia F., Wallgren M., Rogriguez- Martinez H. 2008. Assessment of motility of ejaculated, liquid stored boar spermatozoa using computerized instruments. Theriogenology 69, 1129-1138.

Verstegen J., Iguer-Ouada M., Onclin K. 2002. Computer assisted semen analyzers in andrology research and veterinary practice. Theriogenology $57,149-179$. 
Watson P.F. 2000. The causes of reduced fertility with cryopreserved semen. Anim. Reprod. Sci. 60-61, 481-492.

Yeung C.H., Cooper T.G., Nieschlag E. 1997. A technique for standardization and quality control of subjective sperm motility assessments in semen analysis. Fertil. Steril 67, 1156-1158.

Abstract. The experiment carried out aimed to examine the effectiveness of two methods of assessment of the parameters of sperm motility in thawed semen depending on the degree of its dilution. The semen was collected from 12 Simmental breeding bulls using an artificial vagina. Semen samples were pre-evaluated in terms of volume, colour, $\mathrm{pH}$, viability, concentration and motility and then combined into one pooled sample to eliminate individual differences, cooled to $4^{\circ} \mathrm{C}$, packed in $0.25 \mathrm{ml}$ straw and frozen in liquid nitrogen, stored in a container at $-196^{\circ} \mathrm{C}$. Next they were thawed, divided into samples $A, B$ and $C$, and subsequently diluted $1: 10$ (sample A), $1: 20$ (sample B) and $1: 30$ (sample C) and selected motion parameters were evaluated using conventional microscopic method and computer-aided (CASA). The obtained results were analysed statistically. The total sperm movement analysed by two methods in all tested samples differed significantly $(p<0.05)$. The spermatozoa progressive movement studied by the CASA system differed significantly from the one tested using the conventional method at dilution $1: 20$ and $1: 30(p<0.05)$. The obtained results of the progressive movement at 1:10 dilution using both methods did not differ significantly. Studies have shown that mobility analysis carried out using the CASA system was characterized by greater accuracy and reproducibility of results than the conventional microscopic method. Moreover, the results of the following studies indicate the relationship between the degree of sperm dilution and the reproducibility of results. 
